\title{
Sistem Informasi Eksekutif STMIK Atma Luhur Dengan Penerapan Customer Relationship Management Berbasis Website
}

\section{The Implementation of STMIK Atma Luhur's Executice Information Systems Customer Relationship Management Based on Website}

\author{
${ }^{1)}$ Delpiah Wahyuningsih, ${ }^{2)}$ Hamidah \\ ${ }^{1)}$ Teknik Informatika, ${ }^{2)}$ Manajemen Informatika, STMIK Atma Luhur \\ Jl Jend Sudirman - Selindung Kec Gabek Pangkalpinang \\ ${ }^{1)}$ delphibabel@atmaluhur.ac.id, ${ }^{2}$ hamidah@atmaluhur.ac.id
}

\begin{abstract}
Abstrak
Sekolah Tinggi Manajemen Informatika dan Komputer Atma Luhur adalah sekolah tinggi komputer satu satunya di kepulauan Bangka Belitung. STMIK Atma Luhur mempunyai 3 eksekutif yaitu Yayasan pendidikan Atma Luhur, Ketua STMIK Atma Luhur dan Pembantu ketua I bidang akademik. Semua bagian yang ada di STMIK Atma Luhur akan bertanggung jawab langsung kepada 3 eksekutif tersebut sehingga menghasilkan keputusan yang simpang siur atau berbeda setiap eksekutif. Dengan adanya perbedaan keputusan, maka akan menyebabkan masalah serius yang akan menghambat perkembangan dan kemajuan STMIK Atma Luhur. Sistem pengambilan keputusan eksekutif masih dilakukan secara manual untuk semua bagian. Sistem ini bertujuan untuk memudahkan semua eksekutif dalam memantau semua kegiatan baik kegiatan akademik dan non akademik dengan penerapan Customer Relationship Management (CRM). Pemilihan motode Customer Relationship Management (CRM), karena akan menambah ketertarikan semua bagian dalam mengisi data semua kegiatan yang akan dan telah dilaksanakan, sehingga semua kegiatan pada STMIK Atma Luhur dapat terkontrol dengan baik oleh semua eksekutif.
\end{abstract}

Kata kunci-Sistem Informasi Eksekutif, Customer Relationship Management, Website.

School of Information Management and Computer Atma Luhur high school computer is the only one in the islands of Bangka Belitung. STMIK Atma Luhur has 3 executives, Atma Luhur Education Foundation, Chairman of the Atma STMIK Sublime and Vice chairman of the first academic fields. All parts in STMIK Atma Luhur will be directly responsible to the executive 3 resulting decisions or different maze every executive. With the difference in the decision, it will cause serious problems that would hinder the development and progress of Atma STMIK Luhur. Executive decision-making system is still done manually for all parts. This system aims to facilitate all executives in monitoring all activities both academic and nonacademic activities with the implementation of Customer Relationship Management (CRM). Selection motode Customer Relationship Management (CRM), because it will add to the interest of all sections in filling the data of all activities to be and have been implemented, so that all activities at Luhur STMIK Atma can be well controlled by all executives.

Keywords-Executive Information Systems, Customer Relationship Management, Website. 


\section{PENDAHULUAN}

Pada saat ini kemajuan teknologi berkembang pesat. Perkembangan teknologi saat ini telah merambah ke seluruh penjuru. Perkembangan teknologi saat ini merupakan dasar untuk mengembangkan kehidupan berbangsa dan bernegara. Kemajuan suatu negara didasarkan atas seberapa jauh ilmu pengetahuan dan teknologi yang dikuasai oleh negara tersebut. Hal ini sangat beralasan dikarenakan ilmu pengetahuan dan teknologi merupakan dasar dari setiap aspek kehidupan manusia perkembangan teknologi telah meliputi seluruh dunia bukan hanya ada pada Negara maju tetapi juga pada Negara berkembang, contohnya di negara kita yaitu Indonesia. Di Indonesia kemajuan teknologi masih sangat rendah bahkan bisa dibilang tertinggal jika dibandingkan dengan negara lain baik yang di ibu kota maupun di provinsi bahkan telah merambah ke desa-desa. Hendaknya kita terus meningkatkan perkembangan ilmu pengetahuan dan teknologi untuk memajukan Negara kita.

Sistem informasi eksekutif (SIE) merupakan sistem informasi pada level strategic dari sebuah organisasi yang didesain untuk pengambilan keputusan yang tidak terstruktur melalui grafik dan komunikasi. [1]

Seperti halnya STMIK Atma Luhur disini mempunyai 3 eksekutif yaitu Yayasan pendidikan Atma Luhur, Ketua STMIK Atma Luhur dan Pembantu ketua I bidang akademik. Semua bagian yang ada di STMIK Atma Luhur akan bertanggung jawab langsung kepada 3 eksekutif tersebut sehingga menghasilkan keputusan yang simpang siur atau berbeda setiap eksekutif. Dengan adanya perbedaan keputusan, maka akan menyebabkan masalah serius yang akan menghambat perkembangan dan kemajuan STMIK Atma Luhur. Sistem eksekutif masih dilakukan secara manual untuk semua bagian. Sistem ini bertujuan untuk memudahkan semua eksekutif dalam memantau semua kegiatan baik kegiatan akademik dan non akademik. Melihat dari permasalahan ini maka sangat diperlukannya suatu perangkat lunak sistem informasi eksekutif untuk membantu para pimpinan dalam mengatasi masalah tersebut agar data menjadi lengkap, terpadu, praktis dan mudah serta siap digunakan setiap saat bagi pihak eksekutif STMIK Atma Luhur sehingga dapat mendukung proses pengambilan keputusan secara cepat, tepat dan terarah dan untuk memberikan fasilitas sharing data antar sub bagian. Dalam hal untuk menunjang kebutuhan eksekutif akan informasi, suatu Sistem Informasi Eksekutif juga menawarkan informasi yang dapat berupa laporan dalam berbentuk grafik atau tabel yang mudah dipahami dan dimengerti serta laporan tersebut dapat di drilldown menjadi laporan yang lebih spesifik.

Penelitian terkait yang dilakukan oleh Apriansyah Putra dalam naskah publikasi yang berjudul "Sistem informasi eksekutif berbasis web Studi Kasus : Swalayan Koperasi Petra Pertamina Unit II Plaju" menjelaskan identifikasi spesifik kebutuhan eksekutif sangat berperan penting dan mempengaruhi produk yang dihasilkan yaitu perangkat lunak sistem informasi eksekutif, gambaran prediksi dan perbandingan antara target dari volume penjualan dengan volume penjualan yang didapat pada perangkat lunak sistem informasi eksekutif ini, sangat membantu pimpinan eksekutif dalam membuat suatu perencanaan dan perkiraan-perkiraan serta tindakan apa yang harus diambil, ketersediaan data dari database perusahaan dalam pemenuhan kebutuhan eksekutif sangat berpengaruh dalam penyajian informasi oleh perangkat lunak sistem informasi eksekutif dan persentase jumlah anggota koperasi yang aktif sangat mempengaruhi tinggi rendahnya volume penjualan, hal ini dibuktikan dari informasi pembelian yang dilakukan baik oleh non anggota maupun anggota.

Penelitian terkait yang dilakukan oleh Edy Martha dan Dewi dalam naskah publikasi yang berjudul "Analisis dan perancangan Sistem Informasi Eksekutif Studi Kasus Pada Sekretariat Kabinet" menjelaskan dengan adanya Sistem Informasi Eksekutif ini, eksekutif dapat dengan cepat membaca informasi untuk megetahui perkembangan yang ada. Dengan telah dibuatnya Sistem Informasi eksekutif berbasis web ini, Pimpinan dapat segera membuat analisa 
sebagai dukungan admnistrasi dan teknis serta bahan pemikiran dalam membantu Presiden sebagai Kepala Pemerintahan dalam menjalankan pemerintahan.

Penelitian terkait yang dilakukan oleh Apriansyah dalam naskah publikasi yang berjudul "Sistem informasi eksekutif pembelian dan penjualan berbasis website pada PT. Graha cellular pratama Palembang" menjelaskan dengan adanya website ini general manager dapat memperoleh laporan lebih cepat, mudah dalam melakukan perkiraan order pembelian, dan dapat memantau target penjualan serta pencapaian target penjualan.

\section{METODE PENELITIAN}

A. Sistem Informasi Eksekutif

Sistem informasi eksekutif (SIE) merupakan sistem informasi pada level strategic dari sebuah organisasi yang didesain untuk pengambilan keputusan yang tidak terstruktur melalui grafik dan komunikasi. [1]

Konfigurasi EIS yang berbasiskan komputer biasanya meliputi satu komputer personal. Dalam perusahaan besar PC tersebut dihubungkan dengan mainframe [2], seperti tampak dalam model EIS pada gambar 2.1 Komputer personal eksekutif berfungsi sebagai executive wordstation. Konfigurasi perangkat kerasnya mencakup penyimpanan sekunder, kebanyakan dalam bentuk hard disk, yang menyimpan database eksekutif. Database eksekutif berisi data dan informasi yang telah diproses sebelumnya oleh komputer sentral perusahaan. Eksekutif memilih dari menu untuk menghasilkan tampilan layar yang telah disusun sebelumnya (preformatted), atau untuk melakukan sejumlah kecil pemrosesan.

Sistem ini juga memungkinkan pemakai menggunakan sistem pos elektronik perusahaan dan mengakses data dan informasi lingkungan. Dalam beberapa kasus, personil pendukung EIS memasukkan informasi terbaru.

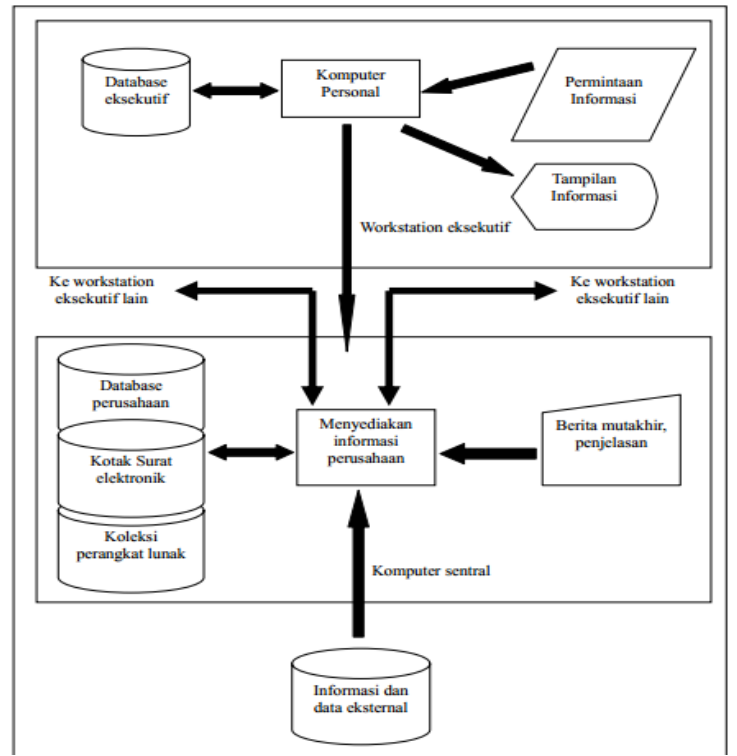

Sumber: McLeod dan Schell, 2001, p330

Gambar 1. Model EIS

B. Web Engineering

Metode pengembangan sistem yang digunakan dalam penelitian ini adalah web engineering (rekayasa web) yaitu suatu model rekayasa perangkat lunak yang digunakan untuk pengembangan aplikasi-aplikasi berbasis web, sedangkan menurut Roger S. Pressman (2005) web engineering adalah suatu proses yang digunakan untuk membuat aplikasi web yang berkualitas tinggi. Web Engineering (Rekayasa Web) tidak sama persis dengan Rekayasa Perangkat Lunak, tetapi RW memiliki konsep dan prinsip mendasar dari Rekayasa Perangkat 
Lunak. Proses di Rekayaa Web lebih ditekankan pada aktivitas teknis dan menajemen yang hampir sama. Tahapan-tahapan dalam rekayasa web antara lain:
a. Customer Communication
b. Planning
c. Modeling (Pemodelan)
d. Construction (Konstruksi)
e. Delivery dan Feedback

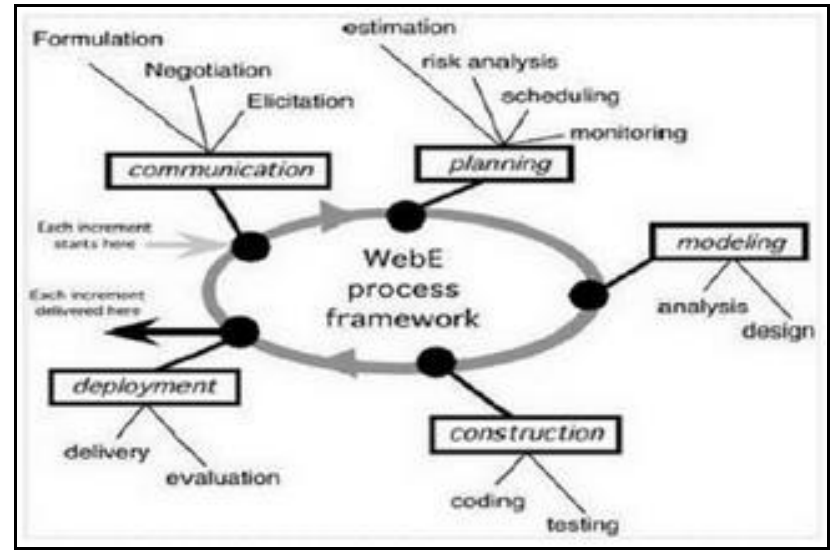

Gambar 2. Web Engineering Process Framework[3]

C. Customer Relationship Management (CRM)

Customer Relationship Management (CRM) menurut Buttle (2007:48) yaitu "CRM adalah strategi inti dalam bisnis yang mengintegrasikan proses-proses dan fungsi -fungsi internal dengan semua jaringan eksternal untuk menciptakan serta mewujudkan nilai bagi para konsumen sasaran secara profitabel". Sedangkan menurut Temporal dan Troot (2002:7) berpendapat bahwa "CRM pada intinya merupakan kolaborasi dengan setiap konsumen yang mampu menciptakan keadaan yang tidak merugikan salah satu pihak (win-win situation). anda menambah nilai pada kehidupan sehari -hari setiap konsumen, dan sebagai imbalannya, mereka memberikan kesetiaan kepada anda.

Kerangka komponen CRM diklasifikasikan menjadi tiga yaitu [8]

1. Operasional CRM : Operasional CRM dikenal sebagai front office perusahaan. Komponen CRM ini berperan dalam interaksi dengan pelanggan. Operasional CRM mencakup proses otomatisasi yang terintegrasi dari keseluruhan proses bisnis, seperti otomatisasi pemasaran, dan pelayanan. Salah satu penerapan CRM yang termasuk dalam kategori operasional CRM adalah dalam bentuk aplikasi web. Melalui web, suatu perusahaan dapat memberikan pelayanan kepada pelanggan.

2. Analitikal CRM : Analitikal CRM dikenal sebagai back office perusahaan. Komponen CRM ini berperan dalam memahami kebutuhan pelanggan. Analitikal CRM berperan dalam melaksanakan analisis pelanggan dan pasar, seperti analisis trend pasar dan analisis kebutuhan dan perilaku pelanggan. Data yang digunakan pada CRM analitik adalah data yang berasal dari CRM operasional.

3. Collaborative CRM: Komponen kolaborasi CRM meliputi e-mail, personalized publishing, ecommunities, dan sejenisnya yang dirancang untuk interaksi antara pelanggan dengan perusahaan. Tujuan utamanya adalah memberikan nilai tambah dan memperluas loyalitas pelanggan ke pelanggan lain yang masih belum berada di level kesetiaan pelanggan. Collaborative CRM juga mencakup pemahaman atau kesadaran bahwa pelanggan yang setia dapat menjadi magnet bagi pelanggan lain. 


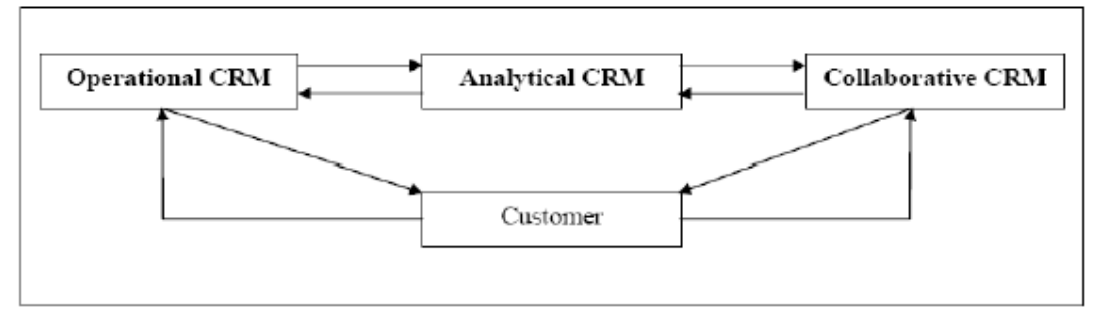

Sumber : [9]

Gambar 3. Kerangka Customer Relationship Management

Tujuan Customer Relationship Management (CRM)

Pada dasarnya, tujuan suatu perusahaan mengadopsi CRM adalah untuk meningkatkan ketahanan dan kepuasan pelanggan. Secara umum dapat dikatakan bahwa tujuan setiap strategi CRM adalah untuk mengembangkan hubungan yang menguntungkan dengan pelanggan. Sasaran utama dari CRM adalah untuk meningkatkan pertumbuhan jangka panjang dan profitabilitas perusahaan melalui pengertian yang lebih baik terhadap kebiasaan (behavior) pelanggan [7].

\section{HASIL DAN PEMBAHASAN}

A. Analisis Sistem Berjalan

STMIK Atma Luhur Pangkalpinang mempunyai kegiatan dibidang akademik maupun non akademik. Untuk mengatur kegiatan tersebut. Pimpinan Atma Luhur membagikan untuk mengelola bidang akademik (proses belajar mengajar, beasiswa, dll), penelitian, pengabdian masyarakat, olahraga, Dari semua kegiatan yang ada di lingkungan Atma Luhur Pangkalpinang terkadang laporan kegiatan tersebut tidak ada, hanya sebagian kegiatan yang mempunyai laporan bahkan pimpinan tidak mengetahui kegiatan apa saja yang diadakan oleh Lingkungan Kampus STMIK Atma Luhur dan berapa kegiatan yang diadakan untuk tiap semester. Data kegiatan setiap semester selalu hilang dan bertanya kepada bagian yang menyelenggarakannya baik bertanya berupa dokumentasi, laporan dan lain-lain. Sehingga kegiatan yang begitu banyak diadakan pimpinan kurang mengetahui kegiatan apasaja yang diadakan dilapangan, dan tidak mengetahui berapa banyak kegiatan yang dilakukan dilingkungan kampus STMIK Atma Luhur Pangkalpinang.

B. Analisis Sistem Di Ajukan

Dari analisis sistem yang berjalan maka disini kami akan membangun sistem untuk mendukung eksekutif kampus Atma Luhur. Berikut analisis sistem yang diajukan. 


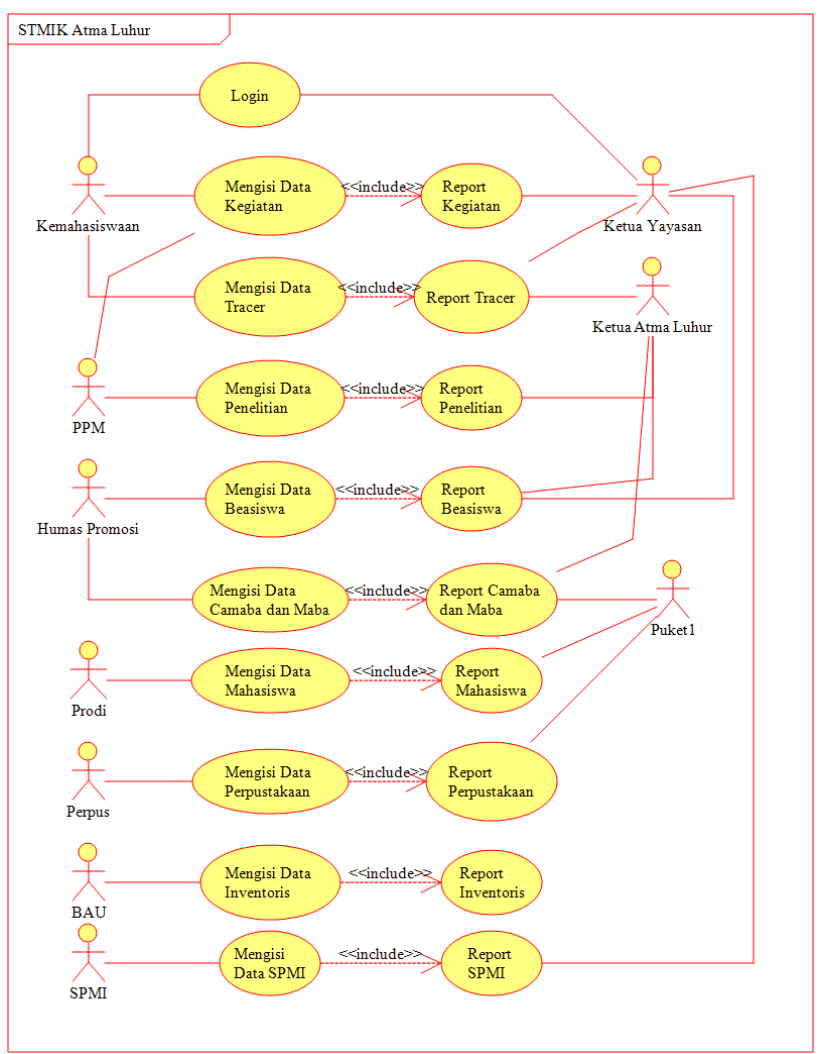

Gambar 4. Sistem yang diajukan

Dari gambar sistem yang diajukan dijelaskan bahwa eksekutif kampus STMIK Atma Luhur dapat memantau, mengetahui, mengendalikan dan melihat berapa banyak kegiatan yang adakan dilingkungan STMIK Atma Luhur. Dimana setiap bagian mengisi data kegiatan yang akan diajukan. Dimulai dari mengisi data proposal kegiatan, dokumentasi kegiatan, serta laporan kegiatan semua di upload melalui sistem informasi eksekutif STMIK Atma Luhur dengan penerapan customer relationship management berbasis website.

Setiap bagian mengisi data melalui website SIE STMIK Atma Luhur penerapan CRM, dimana CRM berfungsi untuk menarik pengguna untuk masuk dan mengisi data ke website. Dan pengguna akan menerima pesan melalui SMS dan pemberitahuan di website jika kegiatan yang diadakan tersebut telah diisi atau belum serta setiap pengguna yang mengisi data kegiatan dengan lengkap ke Website akan tampil dan disetiap tahun akan menampilkan bagian mana saja yang mengisi data dengan lengkap dan kegiatan paling banyak akan mendapat reward dari eksekutif.

\section{Analisis SIE dengan CRM}

Analisis sistem informasi eksekutif dengan penerapan customer relationship management ada hubungannya dengan analisis sistem yang diajukan, dimana telah dijelaskan diatas eksekutif kampus STMIK Atma Luhur ada tiga yaitu Ketua Yayasan, Ketua STMIK dan Pembantu Ketua 1 (bidang akademik). Eksekutif tersebut dapat memantau, mengetahui, memutuskan, melihat kegiatan yang diadakan di lingkungan kampus. Eksekutif dapat melihat berapa kegiatan yang dilakukan dan dapat menjadikan evaluasi setiap tahun dengan grafik kegiatan, grafik proposal kegiatan dan grafik laporan kegiatan yang masuk ke website. Sistem informasi eksekutif dengan penerapan CRM dapat memicu penanggung jawab kegiatan tersebut untuk mengisi ke website. Setiap kegiatan yang telah diisi diawal akan ada pemberitahuan melalui pesan SMS ke penanggung jawab kegiatan jika proposal dan laporan belum dimasukkan ke website. Untuk memantau dan mengevaluasi kualitas website dan kepuasan pengguna maka 
SIE ini akan menyebarkan kuesioner setiap tahunnya kepada pengguna website sistem informasi eksekutif ini.

D. Tampilan Mengisi Kegiatan

Setiap kegiatan yang dilakukan penanggung jawab kegiatan tersebut akan mengisi data kegiatan apa yang akan diadakan. Tampilan sebagai berikut.

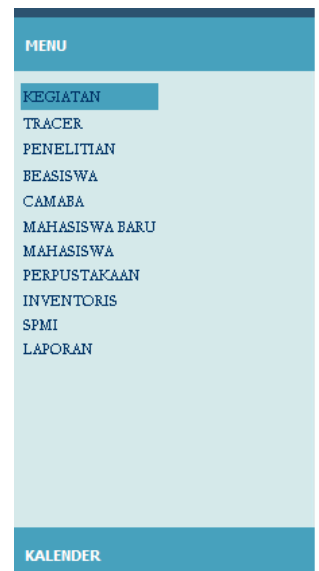

KODE KEGIATAN

NAMA KEGIATAN *

TANGGAL PENGISIAN

TANGGAL KEGIATAN *

LOKASI KEGIATAN

JENIS KEGIATAN

PENYELENGGARA

PENANGGUNGJAWAB KEGIATAN *

HP PENGANGGUNGJAWAB *

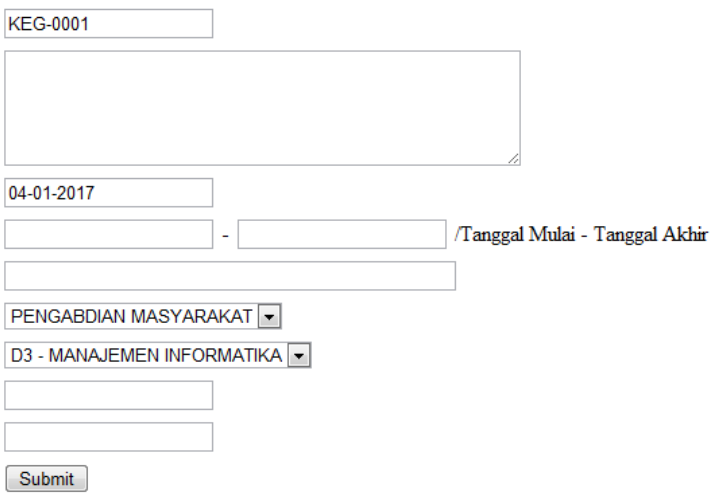

Submit

Gambar 5. Form Kegiatan

Penjelasan dari gambar form kegiatan merupakan untuk mengisi data yang akan diadakan di STMIK Atma Luhur Pangkalpinang. kegiatan apapun harus di isi dan di data untuk pelaporan ke eksekutif Atma Luhur. Pada form kegiatan yang bertanda bintang berwarna merah wajib di isi. Kode kegiatan tidak di isi untuk muncul secara otomatis.

E. Tampilan Mengisi Proposal / Laporan Kegiatan

Setelah form kegiatan di isi maka ada pemberitahuan bahwa kegiatan tersebut di setujui oleh ketua STMIK Atma Luhur. Jika kegiatan tersebut sudah disetujui maka penanggungjawab kegiatan akan mengupload proposal kegiatan yang telah di acc oleh pihak yang bersangkutan.

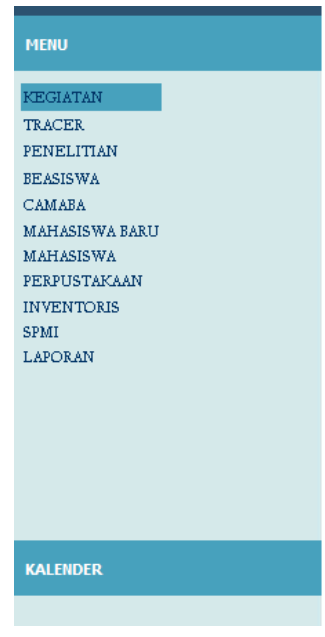

\begin{tabular}{l|l|} 
INPUT PROPOSAL/LAPORAN AKHIR \\
KODE KEGIATAN * \\
NAMA KEGIATAN & KEG-0001- \\
TANGGAL PENGISIAN & $25-01-2017$ \\
TANGGAL KEGIATAN & KEC PUDING BESAR \\
LOKASI KEGIATAN & PENGABDIAN MASYARAKAT \\
JENIS KEGIATAN & D3 - MANAJEMEN INFORMATIKA \\
PENYELENGGARA & DELPIAH WAHYUNINGSI \\
PENANGGUNGJAWAB KEGIATAN & 085267908857 \\
HP PENGANGGUNGJAWAB & PROPOSAL O LAPORAN AKHIR \\
JENIS * & Choose File Laporan Na... 2016.docx \\
UPLOAD PROPOSAL & Choose File No file chosen \\
UPLOAD LAPORAN AKHIR & Submit
\end{tabular}

Gambar 6. Form Proposal / Laporan Kegiatan

Penjelasan dari gambar input proposal / laporan kegiatan yaitu dimana yang di pilih adalah kode kegiatan setelah kode kegiatan dipilih maka nama kegiatan, tanggal kegiatan, lokasi kegiatan sampai no hp penanggung jawab akan muncul secara otomatis. Cukup Pilih Kode Kegiatan, Jenis Kegiatan, dan Upload Proposal/ Laporan Akhir

Jika kegiatan tersebut telah di upload maka penanggungjawab akan menerima pesan bahwa laporan akhir kegiatan telah di terima dan di periksa oleh Ketua STMIK Atma Luhur Pangkalpinang. Yang tampilan sebagai berikut. 


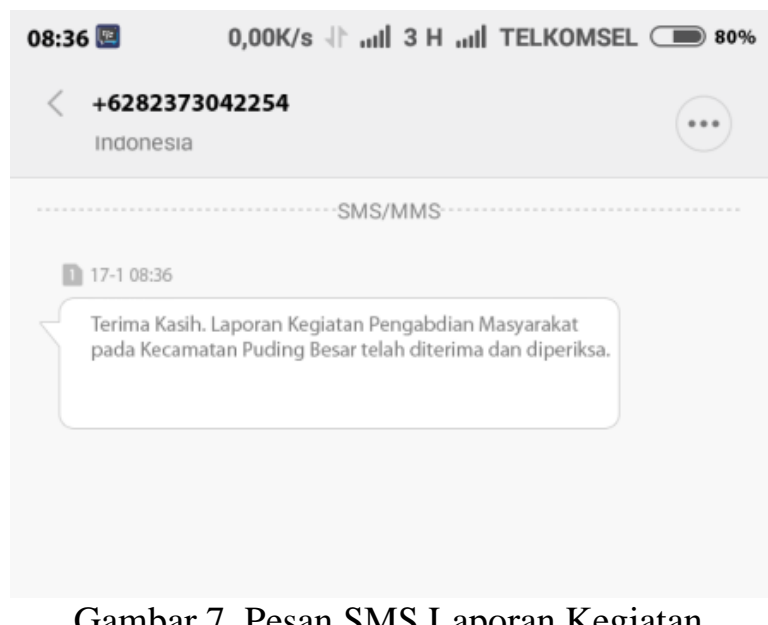

Penjelasan dari gambar pesan SMS Laporan Kegiatan ini merupakan fungsi dari Metode Customer Relationship Management (CRM). Dimana Sistem Informasi Eksekutif ini dapat memudahkan pengguna untuk mengetahui informasi proposal kegiatan, laporan kegiatan atau data akademik yang lainnya. Jika pengguna hanya mengisi kegiatan yang akan diadakan tanpa adanya proposal maupun laporan akhir maka pengguna akan menerima SMS dari SIE ini. Isi SMS yang berupa pemberitahuan bahwa harus segera di upload baik proposal maupun laporan akhir kegiatan.

\section{F. Grafik Proposal}

Grafik proposal kegiatan akan menampilkan proposal kegiatan yang akan diadakan. Untuk pertahun ajaran. Seperti gambar berikut ini.

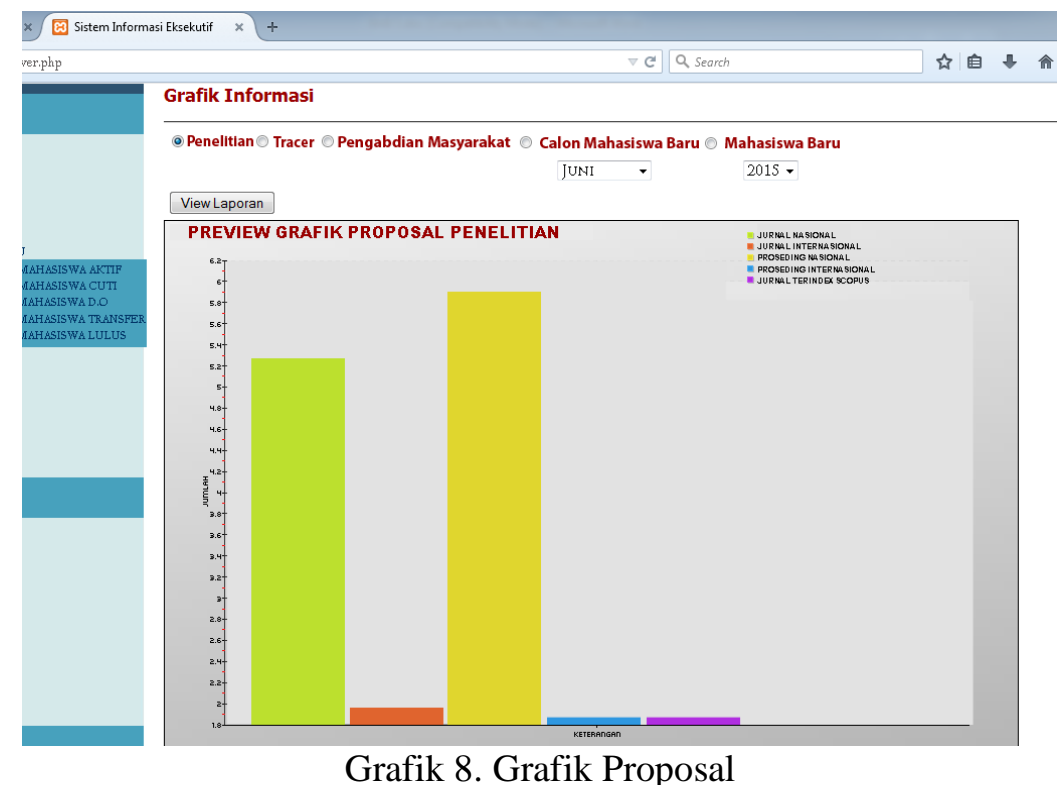

Dari gambar grafik kegiatan diatas maka akan mengetahui perbandingan penelitian yang dikategorikan 5 kategori yaitu jurnal nasional, jurnal internasional, proseding nasional, proseding internasional dan jurna terindex scopus pada tahun tersebut. Garfik kegiatan ini 
menunjukkan secara jelas bahwa penelitian yang ada pada STMIK Atma Luhur Pangkalpinang ada berapa penelitian baik nasional maupun internasional dan baik jurnal maupun proseding.

\section{G. Grafik Laporan}

Grafik laporan STMIK Atma Luhur pangkalpinang yang dapat dilihat pertahun. Yang dilihat oleh eksekutif STMIK Atma Luhur dan pengguna yang lainnya. Grafik laporan ini yang tampil adalah pengguna yang sudah mengupload laporan akhir kegiatan, laporan calon mahasiswa baru, mahasiswa baru, mahasiswa aktif, mahasiswa cuti, mahasiswa drop out, mahasiswa transfer, pengabdian masyarakat, penelitian, tracer studi, tracer alumni, beasiswa, mahasiswa lulus, data perpustakaan (langganan jurnal akreditasi dikti, buku, majalah dan lainlain). Grafik ditampilkan perkagetori.

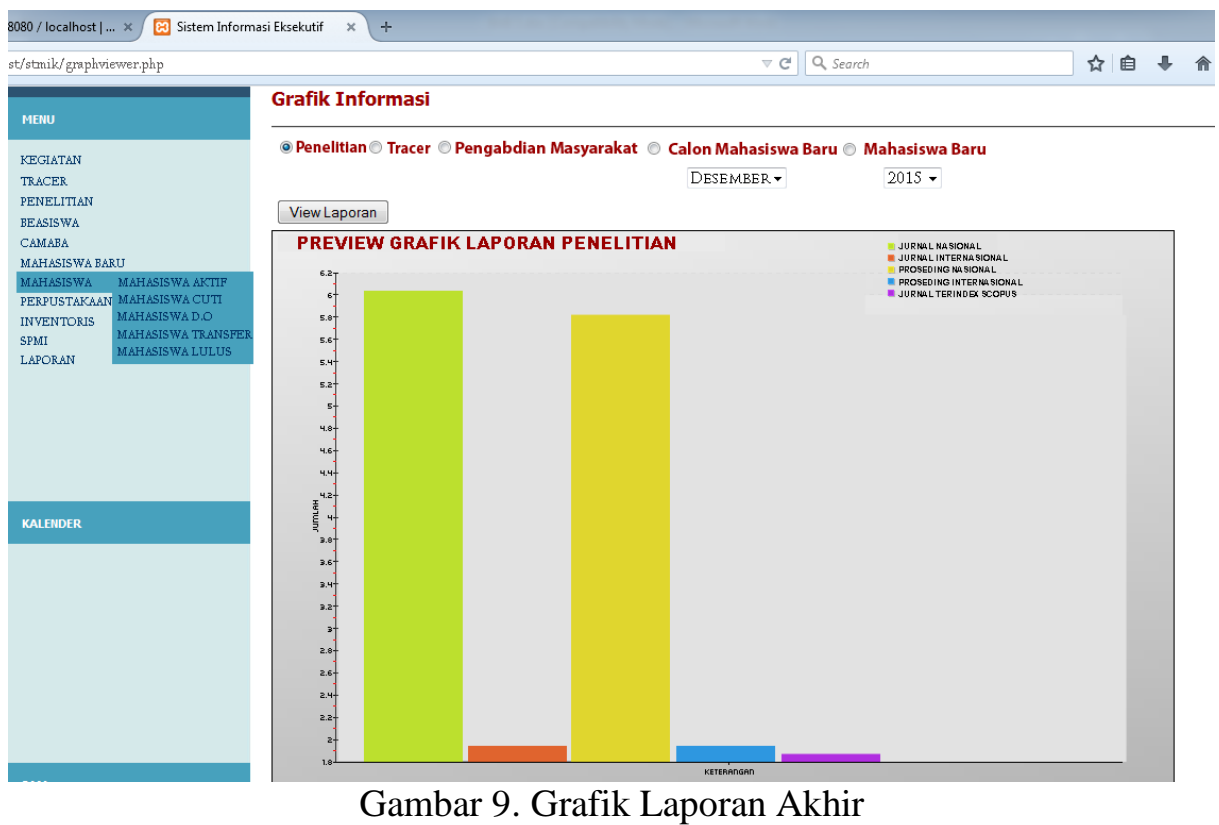

Pada gambar grafik laporan akhir yaitu salah satu tampilan grafik penelitian pada Desember 2015. Grafik tersebut menampilkan data jumlah penelitian pada tahun 2015, dari januari sampai desember 2015. Informasi yang diberikan adalah jumlah jurnal nasional, jurnal internasional, proseding nasional, proseding internasional dan jurnal terindex scopus. Semua data yang tampil tersebut merupakan kontribusi dosen maupun dosen kolaborasi dengan mahasiswa di lingkungan STMIK Atma Luhur Pangkalpinang.

\section{KESIMPULAN}

Berdasarkan pembahasan di atas maka dapat disimpulkan bahwa:

a. Sistem Informasi Eksekutif STMIK Atma Luhur yang berbasis website meringankan proses pengumpulan berkas secara elektronik untuk semua bagian pejabat, dosen dan staf.

b. Sistem Informasi Eksekutif ini memudahkan para eksekutif Atma Luhur dalam melihat data baik data yang sekarang maupun yang sebelumnya, SIE berbasis website ini yang akan menjadi evaluasi terhadap Atma Luhur itu sendiri.

c. SIE berbasis website dengan penerapan Customer Relationship Management memudahkan antara admin dan pengguna yang lainnya. Proses CRM berupa pengiriman pesan via SMS melalui website yang dikirimkan kepada pengguna yang mengisi data kegiatan, data mahasiswa dan lain-lain. 
d. Terapan SIE pada sistem ini yaitu eksekutif dan pengguna dapat melihat perbandingan jumlah kegiatan, mahasiswa, penelitian, pengabdian, tracer studi, tracer alumni, dan lainlain yang ditampilkan dalam bentuk grafik. Tampilan Grafik dapat dilihat pertahun akademik.

e. SIE berbasis website ini dapat mempermudah eksekutif, pejabat, dosen serta staf untuk mencetak ulang dokumentasi baik akademik maupun non akademik terutama untuk keperluan akreditasi institusi dan prodi.

\section{SARAN}

Saran dari penulis untuk sistem informasi eksekutif pada STMIK Atma Luhur yaitu

a. Diharapkan sistem informasi eksekutif ini dapat ditambahkan penerapan CRM broadcast secara otomatis dengan waktu yang diberikan untuk pemberitahuan segera uploadkan data kegiatan/penelitian/pengabdian dan lain-lain.

b. Dikembangkan pada grafik penelitian untuk ditampilkan penelitian perprogram studi masing-masing.

c. Sistem ini perlu dikendalikan untuk pemantauan lebih lanjut.

\section{UCAPAN TERIMA KASIH}

Alhamdullilah atas Rahmat Allah SWT dan penuh rasa syukur senantiasa penulis panjatkan kehadirat Allah SWT dan shalawat dan salam senantiasa tercurahkan kepada junjungan Nabi besar Muhammad SAW, keluarga dan para sahabat rasullah. Penulis menyampaikan rasa terima kasih yang sebesar-besarnya kepada Yayasan dan Ketua STMIK Atma Luhur serta seluruh bagian penting jajaran pejabat yang telah mendukung dalam penelitian ini. Semoga penelitian ini bermanfaat bagi penulis pada khususnya dan pembaca pada umumnya.

\section{DAFTAR PUSTAKA}

[1] Laudon, K. dan Jane, P. 2004. Management Information System. Managing The Digital Firm. New Jersey : Prentice-Hall, Inc.

[2] McLeod, dkk. 2001. Management Information System. London : International Prentice Hall, Inc.

[3] Pressman 2002, Rekayasa Perangkat Lunak, Andi, Yogyakarta.

[4] Putra, Apriansyah. Jurnal: Sistem informasi eksekutif berbasis web. 2005. http://eprints.unsri.ac.id/5594/1/Jurnal Matrik.pdf.

[5] Martha, Edy dan Dewi Agushinta R. Jurnal: Analisis dan Perancangan Sistem Informasi Eksekutif Studi Kasus pada Sekretariat Kabinet. UAJY: 2012. https://fti.uajy.ac.id/sentika/publikasi/makalah/2012/2012-1.pdf

[6] Eka Brizman, Dienniyah Manggiasih dan Yulistia. Jurnal : Sistem Informasi Eksekutif Pembelian dan Penjualan Berbasis Website Pada PT. Graha Cellular Pratama Palembang. 2007.http://eprints.mdp.ac.id/962/1/Jurnal\%202007240193\%20Brizman_Eka_Cassandra, $\% 202007240196 \% 20$ Dienniyah Manggiasih.pdf.

[7] D. Kurniawan, "Penerapan Aplikasi CRM (Customer Relationship Management) Berbasis Web dalam Bidang Jasa", 2009. [Online]. Available:

http://wiechan.blog.binusian.org/files/2009/06/penerapan-crm-basis-web-dalam-bidangjasa1.doc. [Accessed 20012].

[8] T. Efraim, "Sistem Pendukung Keputusan dan Sistem Cerdas", Yogyakarta, ANDI, 2005. 
[9] Wijayanti, Teti and I Azhari, "Pengembangan Customer Relationship Management Berbasis Web pada Griya Muslim Flora,"2009.[Online].Available:

http://is.uad.ac.id/jusi/files/02-JUSI-Vol-1-No-1-_Pengembangan-E-CRM-Berbasis-Webpada-Griya-Muslim-Flora.pdf. [Accessed 2012].

[10] Buttle, Francis. 2007. Customer Relationship Management (Manajemen Hubungan Pelanggan). Terjemahan oleh Arief Subiyanto. Malang : Bayu Media Publishing.

[11] Temporal, Paul dan Martin Troot. Romancing the Customer. Terjemahan oleh Kusnandar. Jakarta : Salemba Empat. 